\title{
Peradilan Internasional dan Diplomasi dalam Sengketa LingKungan Hidup Maritim
}

\author{
Oleh: Andreas Pramudianto ${ }^{1}$
}

\begin{abstract}
Abstrak
Putusan Mahkamah Arbitrase Permanen (Permanent Court of Arbitration/PCA) baru-baru ini untuk penyelesaian sengketa maritim di Laut China Selatan antara China (Tiongkok) dengan Filipina telah menunjukan bahwa semakin pentingnya penyelesaian sengketa melalui badan peradilan internasional. Walaupun putusan ini sulit untuk dieksekusi, namun peran peradilan internasional tetap menjadi pilihan yang penting di masa mendatang. Di sisi lain jalur diplomasi masih tetap dilakukan baik sebelum sengketa, masa sengketa maupun berakhirnya sengketa. Sengketa maritim terkait lingkungan hidup yang selama ini disidangkan dan diputuskan di beberapa peradilan internasional seperti Mahkamah Internasional (International Court of Justice/ICJ), Studi ini mencoba untuk mendeskripsikan kasus lingkungan hidup maritim melalui jalur diplomasi dan peradilan internasional sehingga mampu memberikan hasil yang bermanfaat bagi pengembangan hukum dan hubungan internasional. Kesimpulan menunjukan bahwa diplomasi dan putusan peradilan internasional telah memberikan dasar dan petunjuk hukum bagi negara-negara dan aktor bukan negara dalam hubungan internasional.
\end{abstract}

Kata kunci : Lingkungan hidup maritim; diplomasi; peradilan internasional; putusan arbitrase Laut China Selatan; amicus curiae.

1 Penulis merupakan Dosen di Sekolah Ilmu Lingkungan Universitas Indonesia (SIL-UI), serta Peneliti di Pusat Penelitian Sumberdaya Manusia dan Lingkungan Sekolah Ilmu Lingkungan Universitas Indonesia (PPSML SIL-UI), 


\section{Abstract}

The Permanent Court of Arbitration (PCA) decision for maritime dispute resolution in the South China Sea between China and the Philippines has shown that the importance of dispute resolution through the international judiciary. Although this decision is difficult to execute, the role of international justice remains an important choice in the future. On the other hand the diplomatic pathway is still done well before, at the time or the end of the dispute. The related environmental maritime disputes that have been tried and decided in several international courts such as the International Court of Justice (ICJ), This study attempts to describe maritime environmental cases through international diplomatic and judicial channels so as to provide useful outcomes for the development of international law and international relations. A provisional conclusion shows that international judicial and diplomacy have provided the legal basis and legal guidance.

Keywords: maritime environment; diplomacy; international justice; South China Sea arbitration; amicus curiae.

\section{Pendahuluan}

Putusan Mahkamah Arbitrase Permanen (Permanent Court of Arbitration/ PCA) di Den Haag, Belanda pada 12 Juli 2016 salah satunya menegaskan bahwa Cina (Tiongkok) tidak mempunyai bukti sejarah kepemilikan dan kekuasaan atas perairan yang dipersengketakan oleh Filipina di Laut Cina Selatan. Di sisi lain putusan PCA juga menegaskan bahwa tindakan Tiongkok dalam membangun dermaga telah menimbulkan kerusakan terumbu karang dan gangguan terhadap habitat serta satwa langka di sekitar perairan tersebut. Namun Mahkamah Arbitrase Permanen (PCA) ternyata tidak memiliki jurisdiksi atau kewenangan untuk memaksakan Tiongkok dalam menerapkan putusan itu. Di sisi lain, kemenangan Filipina dalam sengketa Laut Cina Selatan ini dapat mempengaruhi pihak lain yang juga mengklaim sebagian perairan Laut Cina Selatan, seperti Taiwan, Vietnam, Malaysia dan Brunei untuk melakukan tindakan yang sama². Di sisi lain, putusan

2 Pengaruh putusan PCA ini mulai dirasakan baru-baru ini dimana Philipina mengganti nama Laut China Selatan menjadi Laut Filipina Barat (Philipina) dan Indonesia mengganti menjadi Laut Natuna Utara (Indonesia) yang kemudian diprotes oleh China, dalam http:// ekonomi.kompas.com/read/2017/07/16/113255326/beijing-protes-indonesia-ubah-lautchina-selatan-jadi-laut-natuna, diunduh pada 28 Juli 2017. 
ini ternyata mampu meredakan ketegangan antara China dengan Filipina yang awalnya bersikeras akan menggunakan senjata. Penyelesaian sengketa lingkungan hidup internasional terkait maritim (international environmental maritime dispute resolution) merupakan salah satu permasalahan yang menarik untuk dikaji lebih dalam dalam studi hukum internasional maupun hubungan internasional.

Selama ini, tidak semua perkara yang masuk ke Peradilan internasional, berhubungan dengan lingkungan hidup dan maritim. Namun demikian, dalam prakteknya muncul beberapa kasus yang diproses dalam peradilan internasional terkait lingkungan hidup maritim. Untuk menangani permasalahan atas kasus yang masuk, maka diperlukan berbagai cara seperti yang dilakukan Mahkamah Internasional (International Court of Justice/ICJ) yang telah menerima perkara yang berhubungan dengan lingkungan hidup walaupun tidak berhubungan dengan maritim yaitu Case Concerning Certain Phosphate Lands in Nauru (Nauru v Australia) dan Gabcikovo-Nagymaros Project (Hungary v. Slovakia). Dua kasus ini agak berbeda dan memiliki karakteristik tersendiri dibandingkan dengan kasus sebelumnya. Sebagai awal untuk menangani kasus ini, maka berdasarkan pertimbangan Pasal 26 Piagam Mahkamah Internasional telah dibentuk the Chamber of Environmental Dispute pada 19 Juli $1993^{3}$ Kamar sengketa ini diharapkan menjadi bahan dasar untuk menangani sengketa lingkungan hidup baik di daratan maupun di lautan. Namun amat disayangkan, kamar sengketa ini terhenti dan dibubarkan walaupun kasus ini tetap berjalan.

Melalui artikel yang sangat terbatas ini berbagai cara penyelesaian sengketa maritim telah dilakukan dan dalam prakteknya telah mampu memberikan peredaan ketegangan (détente) dalam hubungan internasional bagi negara-negara bersengketa maupun negara-negara sekitarnya. Pada artikel ini akan dijelaskan mengenai sengketa maritim lintas batas negara (transboundary) yang dimunculkan oleh negara-negara bersengketa melalui sengketa secara damai baik jalur diplomasi maupun pendayagunaan beberapa badan peradilan internasional. Beberapa kasus untuk pembelajaran yang dibangun dalam artikel ini diantaranya kasus Behring Sea

3 ICJ Communique 93/20, 19 Juli 1993. Kamar Penyelesaian Sengketa Lingkungan Hidup (Chamber of Environmental Disputte Settlement) terdiri atas 7 orang hakim yaitu Schwebel, Bedjaoui, Evensen, Shahabudeen, Weeramantry, Ranjeva dan Herczegh. Tugas dari kamar ini akan berlaku efektif sejak tanggal 6 Agustus 1993 seperti dalam Sands, P. 1993. Greening International Law, Earthscan Publications Ltd, London. hlm xix dan hlm. 171. 
Fur (1893), kasus the Trial Smelter (1941), kasus the Corfu Chanel (1948) kasus The Sunrise Artic (2013), kasus Laut China Selatan (2016) dan beberapa kasus lainnya yang bermanfaat bagi pengembangan hukum internasional khususnya hukum lingkungan internasional.

\section{Kajian Teoritik Penyelesaian Sengketa Maritim}

Hukum internasional memiliki sumber yang terpenting seperti tercantum dalam Pasal 38 (1) Statuta Mahkamah Internasional (ICJ) terutama terkait dalam penyelesaian sengketa internasional. Sumber hukum internasional seperti perjanjian internasional, hukum kebiasaan internasional, prinsip-prinsip hukum umum, putusan hakim serta doktrin menjadi dasar dalam memutuskan sengketa yang diajukan kepada Mahkamah Internasional (ICJ). Sengketa internasional (dispute settlement) dapat terbagi dalam bentuk legal dan non legal. ${ }^{4}$ Di sisi lain, tidak semua aktor atau entitas internasional boleh bersengketa dalam peradilan internasional tertentu. Karena itu hukum internasional mengenal subjek hukum internasional yaitu negara, individu, organisasi internasional dan beberapa yang lain seperti Vatikan, Palang Merah internasional dan kaum pemberontak. ${ }^{5}$ Subjek hukum internasional dalam hal tertentu boleh berperkara dalam peradilan internasional seperti di Mahkamah Internasional (ICJ), Mahkamah Hukum Laut (ITLOS), Mahkamah Kejahatan Internasional (ICC). Sementara itu untuk perusahaan multinasional (Multinational Corporation/MNC) maupun Organisasi Non Pemerintah (Non Governmental Organization/NGO) sebagai entitas bukan subjek hukum internasional tidak memiliki hak untuk mengajukan perkaranya (legal standing) di beberapa peradilan internasional. ${ }^{6}$

Karena itu sumber hukum internasional dan subjek hukum internasional menjadi sangat penting dalam memahami penyelesaian sengketa internasional. Menurut beberapa ahli hukum internasional, penyelesaian sengketa dapat

4 Anton, Donald $\mathrm{K}$ et al, International Law : Cases and Materials, Oxford University Press, 2005, hlm 41.

5 Ibid

6 Pernyataan ini ditegaskan dalam Pasal 26 Statuta Mahkamah Internasional dimana hanya negara yang boleh berperkara di hadapan Mahkamah. 
digolongkan dalam 2 kategori yaitu :

a. Penyelesaian sengketa secara damai

Para pihak yang terlibat sengketa bermufakat untuk mencari penyelesaian secara bersahabat.

b. Penyelesaian sengketa secara paksa

Pemecahannya ditempuh secara paksa atau dengan kekerasan.

Untuk kategori mengenai penyelesaian sengketa di bidang lingkungan hidup maritim, umumnya dilakukan secara damai dan jarang dilakukan dengan kekerasan. Sedangkan, penyelesaian sengketa secara paksa dengan kekerasan dapat terjadi berkaitan dengan masalah perebutan sumberdaya alam atau sengketa lainnya yang mengakibatkan tindakan paksaan oleh suatu negara kepada negara lainnya. ${ }^{8}$ Dalam tulisan ini umumnya dibahas penyelesaian sengketa secara damai.

Merrilss mendefinisikan sengketa sebagai perselisihan mengenai fakta, hukum atau politik dimana tuntutan atau pernyataan suatu pihak ditolak, dituntut balik atau diingkari oleh pihak lain. ${ }^{9}$ Dalam sengketa internasional dapat dikatakan ada, bila perselisihan seperti ini yang melibatkan pemerintah, lembaga, badan hukum atau individu dalam bagian dunia yang berlainan. Dari definisi diatas nampak bahwa tidak hanya persoalan hukum, akan tetapi juga politik memainkan peran penting dimana diplomasi merupakan salah satu alat politik yang penting. Selain itu, adanya perbedaan pendapat serta kepentingan juga merupakan masalah utama yang menyebabkan timbulnya perselisihan. Dalam Behring Sea Fur Case (1893) Inggris berpendapat bahwa tindakan Amerika Serikat yang telah membeli Alaska berdasarkan perjanjian tahun 1867 antara Rusia dengan Amerika Serikat sehingga memperluas jurisdiksinya ternyata telah menimbulkan kerusakan pada

7 JG Starke, Introduction to International Law diterjemahkan oleh Sumitro L.S. Danuredjo, Pengantar Hukum Internasional, Aksara Persada Indonesia, Jakarta: 1989, hal.171. Bandingkan dengan karya J.L. Brier ly, atau para pengarang Indonesia seperti Wiryono Projodikoro, Ali Sostroamidjoyo.

8 Misalnya dalam kasus peledakan senjata nuklir oleh Perancis dimana Australia merasa dirugikan karena wilayah udaranya tercemar. Australia kemudian melakukan tindakan boikot terhadap barang-barang Perancis. Hal ini merupakan salah satu penggunaan secara paksa terhadap penyelesaian sengketa. Lihat selanjutnya Starke, op.cit., hlm 203.

9 J.G. Merrills. International Disuputte Settllement disadur oleh Achmad Faudzan, Penyelesaian Sengketa Internasional, Tarsito, Bandung: 1986, hlm 1. 
kapal Inggris ${ }^{10}$. Tetapi Amerika Serikat menyatakan bahwa jurisdiksi itu diperluas untuk melindungi anjing laut dari perburuan kapal-kapal Inggris. Selain itu sengketa dapat timbul karena diperlukan penegasan hak jurisdiksi khususnya kata Pacific Ocean seperti pada perjanjian tahun 1825 antara Inggris dengan Russia. ${ }^{11}$

Dalam kerangka mencapai kesepakatan untuk diselesaikan melalui jalur arbitrase dan pembentukan perjanjian internasional, maka jalur diplomasi juga dilakukan oleh pemerintah Inggris kepada pemerintah Amerika Serikat. Hal ini dibuktikan melalui surat menyurat diplomatik antara Lord Salisbury ke Sekretriat Negara Amerika Serikat (US Secretary of State). ${ }^{12}$ Cooper berpendapat bahwa sengketa lingkungan hidup internasional timbul ketika adanya suatu konflik kepentingan antara dua negara atau lebih (atau orang-orang dalam negara) mengenai perubahan dan kondisi (baik kualitatif maupun kuantitatif) lingkungan hidup fisik. ${ }^{13}$ Dari pendapat Cooper ini masalah utama terletak pada perubahan lingkungan hidup yang dapat mengganggu negara lain atau orang-orang di dalam suatu negara. Dalam Nuclear Test Case (1974) (Australia v. Perancis) (Selandia Baru v. Perancis) tindakan Perancis yang melakukan uji coba senjata nuklir di wilayah kepulauan Pasifik telah digugat oleh Australia dan Selandia Baru dengan alasan bahwa telah terjadi perubahan lingkungan hidup dimana tes nuklir ini menyebabkan jatuhnya debu radioaktif baik di daratan maupun lautan di kedua negara ini.

Dari pendapat-pendapat diatas dapat diketahui bahwa pada prinsipnya sengketa internasional timbul karena adanya konflik diantara pihak-pihak. Suatu aktivitas yang terjadi di suatu negara kadang-kadang menimbulkan gangguan pada negara lain. ${ }^{14} \mathrm{Hal}$ ini tentu saja menimbulkan konflik bagi negara lain jika

10 Foster, John W. Results of the Bering Sea Arbitration, The North American Review, Vol. 161. No. 469, 2013, hlm. 702.

11 Diedit dari Parry and Grant. Encyclopaedic Dictionary of International Law, Oceana Publication, 1986, hlm. 42.

12 Cairo AR Robb, et al. International Environmental Law Report, Volume 1, Cambridge University Press, 1999, hlm. 50-53

13 Cooper, Catherine. A. 1986. The Management of International Environmental Disputes in the Context of Canada-United States Relations : A Survey and Evaluation of Techniques and Mechanisms dalam Canadian Year Book of International Law Vol 24 Januari 1987, hlm. 247-313.

14 Mengenai masalah ini telah dinyatakan dalam Prinsip 21 Deklarasi Stockhlom 1972 dan Prinsip 2 Deklarasi Rio 1992 yang menyatakan :

"States have, in accordance with the Charter of the United Nations and the principles of international law, the soverign right to exploit their own resources pursuant to their own environmnet and development policies, and the responsibility to ensure that activities within their jurisdiction or control do not cause damage to the environmnet of other States or of areas beyond 
tidak segera diselesaikan. Sebagai contoh dalam The Trial Smelter Case (1941) (USA $v$ Canada), suatu pabrik peleburan tembaga (smelter) di Trial, British Colombia, Kanada telah menimbulkan pencemaran udara dan merusak tanaman serta menimbulkan gangguan kesehatan pada penduduk yang berada di 7 wilayah negara bagian Washington (Amerika Serikat) sehingga menimbulkan konflik antar negara. Timbulnya konflik ini dapat diselesaikan melalui jalur diplomasi dan arbitrase yang pada intinya harus disepakati oleh pihak-pihak yang bersengketa. Diplomasi ditempuh diantaranya melalui surat diplomatik ${ }^{15}$ dan proses negosiasi yang akhirnya disepakati oleh Amerika Serikat dan Kanada melalui pembentukan arbitrasi yang akhirnya pada 15 April 1935 ditandatangani Convention for the Final Settlement of the Difficulties Arising throught the Complaints of Damage Done in the States of Washington by Fumes Discharged from the Smelter of the Consolidated Mining and Smelting Company, Trial British Columbia. Banyak model penyelesaian sengketa internasional yang telah dikenal baik secara teori maupun praktek. Tahun 1907 pernah ditandatangani Hague Convention on the Pacific Settlement of International Disputes. Mengenai penyelesaian sengketa secara damai, Starke membagi menjadi 4 model yaitu :16
a. Arbitrasi
b. Penyelesaian yudisial
c. Perundingan, jasa-jasa baik, perantaraan, pendamaian atau penyelidikan.
d. Penyelesaian di bawah PBB

Sedangkan Akehurst membagi menjadi 3 model yaitu non-judicial methods of settlement, setllement of disputes under the United Nations Charter, arbitration and judicial setllement. ${ }^{17}$ Berbeda dengan Merrills yang membagi menjadi beberapa cara

the limits of national jurisdiction".

(Negara-negara, sesuai dengan Piagam PBB dan prinsip-prinsip hukum internasional, mempunyai kedaulatan untuk memanfaatkan sumberdaya alam mereka sesuai dengan kebijakan di bidang lingkungan hidup dan pembangunan dan berkewajiban pula agar kegiatan yang berada dalam wilayah dan wewenangnya tidak akan menyebabkan timbulnya kerusakan terhadap lingkungan hidup di negara lain dan di wilayah di luar batas yurisdiksi nasionalnya).

Prinsip ini kemudian tegaskan dalam Pasal 3 Konvensi Keanekeragaman Hayati 1992.

15 Surat WR Castle kepada William Phillips (US Departement State) tertanggal 20 Agustus 1927 dalam Keith A Muray.1972. The Trial Smelter Case : International Air Pollution in the Columbia Valley dalam http : www. ojs.library.ubc.ca , hlm. 74

16 Starke, J.G., op.cit., hlm 172.

17 Michael Akehurst, A Modern Introduction to International Law, 4th ed., George Allen \& Unwin (Publishers) Ltd, London: 1989, hlm 201. 
yaitu : negosiasi, mediasi, penyelidikan, konsiliasi, arbitrasi, pengadilan dunia, konvensi hukum laut, PBB dan organisasi regional. ${ }^{18}$

Dalam penyelesaian kasus lingkungan hidup telah ada dokumen yang bersifat soft law sebagai patokan dalam penyelesaian sengketa lingkungan hidup. ${ }^{19}$ Dokumen ini merupakan hasil KTT Rio 1992 yaitu Deklarasi mengenai Lingkungan dan Pembangunan atau disebut Deklarasi Rio 1992. Prinsip 26 menyatakan :

"States shall resolve all their environment disputes peacefully and by appropriate means in accordance with the Charter of the United Nations."

(Negara-negara hendaknya menyelesaikan perselisihan di bidang lingkungan hidup secara damai dan melalui cara yang baik sesuai dengan Piagam PBB).

Berkaitan dengan prinsip diatas, penyelesaian sengketa lingkungan hidup maritim paling tidak berpedoman pada Piagam Perserikatan Bangsa-bangsa (Charter of United Nations) khususnya Bab VI yang mengatur mengenai masalah penyelesaian pertikaian secara damai. Mengenai cara yang digunakan untuk menyelesaikan sengketa Pasal 33 (1) Piagam PBB menyatakan :

"Pihak-pihak yang tersangkut dalam suatu pertikaian yang jika berlangsung terus menerus mungkin membahayakan pemeliharaan perdamaian dan keamanan internasional, pertama-tama harus mencari penyelesaian dengan jalan perundingan, penyelidikan, dengan mediasi, konsiliasi, arbitrasi, penyelesaian menurut hukum melalui badan-badan atau pengaturan-pengaturan regional, atau dengan cara damai lainnya yang dipilih mereka sendiri."

Sehingga berdasarkan pasal diatas, Perserikatan Bangsa-bangsa menggunakan beberapa model atau cara penyelesaian sengketa yaitu : a) perundingan ; b) penyelidikan ; c) Mediasi ; d) Konsiliasi ; e) Arbitrasi ; f) Hukum internasional regional ; g) Pengaturan badan-badan regional ; h) Cara lainnya yang dipilih para pihak.

18 Merrills kemudian membagi lagi menjadi dua kelompok yaitu penyelesaian diplomatik yang terdiri dari negosiasi, mediasi, penyelidikan, konsiliasi dan penyelesaian hukum yang terdiri dari arbitrasi dan penyelesaian yudisial. Merrills. op.cit., hlm. 72.

19 Mengenai masalah soft law baca selanjutnya Andreas Pramudianto, Soft Law Dalam Perkembangan Hukum Lingkungan Internasional dalam Majalah Hukum Pro Justitia Tahun XIII No. 4 Oktober 1995. 


\section{Penyelesian Sengketa Melalui Jalur di Luar Peradilan}

Penyelesaian sengketa di luar peradilan sering disebut sebagai Alternative Dispute Resolution (ADR). Dalam ADR salah satunya adalah negosiasi dimana juga melekat dengan diplomasi seperti dinyatakan diplomacy as "the conduct of international relations by negotiation. ${ }^{20}$ Dengan demikian penyelesaian sengketa diluar pengadilan dalam artikel ini juga termasuk jalur diplomasi. ${ }^{21}$ Melalui jalur diplomasi ini terjadi proses diplomasi terlebih dahulu sebelum kasus dapat diselesaikan dan bahkan jika kasus dapat diselesaikan maka tidak perlu harus ke pengadilan internasional seperti Mahkamah Internasional (ICJ) atau Mahkamah Hukum Laut Internasional (ITLOS).

Kedudukan dan peran diplomasi dalam bersengketa dapat berpengaruh pada keterlibatan suatu negara untuk bersengketa di pengadilan. Proses diplomasi dapat terjadi pada saat sengketa kemungkinan akan terjadi (pre-existing dispute), sengketa muncul (pactum de compromittendo), sengketa sedang berjalan (on going dispute), sengketa berakhir (final dispute) dan pasca sengketa (post-dispute). Sebagai contoh dalam perkara Sipadan-Ligitan Case (Indonesia v Malaysia) diplomasi untuk membuat special agreement untuk menyelesaikan kasus ini ke Mahkamah internasional (ICJ) dilakukan pertemuan diplomatik tahun 1991-1994 melalui Joint Working Group (JWG) yang akhirnya sepakat untuk ditandatangani di Kuala Lumpur, Malaysia pada 31 Mei 1997. Contoh lain pada saat sengketa muncul maka surat Wakil Menteri Luar Negeri Albania telah dibaca oleh Mahkamah Internasional sebagai pernyataan kesepakatan yang mengikat dan tunduk pada jurisdiksi untuk menyelesaikan sengketanya dalam Corfu Chanel Case (1949) (UK v Albania) ${ }^{22}$. Tindakan diplomasi oleh Albania ini disebut sebagai tindakan memenuhi

20 Oxford English Dictionary dalam Jonsson, Crister dan Karin Aggestam. “Diplomacy and Conflict Resolution", Prepared for the NISA conference on "Power, Vision and Order in World Politics", Odense, 23-25 May, 2007.

21 Lihat Huala Adolf, 2004, Umunadi, Ejiwoke Kennedy, 2011, http://www.unwatercoursesconvention.org/the-convention/,

22 Huala Adolf, "Hukum Penyelesaian Sengketa, Tanpa Penerbit". Diakses melalui http://blog. ub.ac.id/devitrirahayu/files/2012/03/3-HUKUM-PENYELESAIAN-SENGKETA-INTERNASIONAL1.pdf 
doktrin forum prorogatum. Pentingnya diplomasi akan menentukan keberhasilan di kemudian hari dalam proses penyelesaian sengketa. Hal ini dilakukan dengan jalur penyelesaian sengketa secara damai melalui diplomasi untuk menentukan status kepemilikan pulau Palmas (Miangas) serta menentukan siapa dan darimana arbitrator akan dipilih, merupakan proses diplomasi yang harus dilakukan antara pemerintah Amerika Serikat dan Ratu Belanda agar tercapai hasil yang memuaskan para pihak. Acta Compromis akhirnya disepakati dan ditandatangani pada 23 Januari 1925 dimana Presiden Konfederasi Swiss akan ditunjuk dalam memilih arbitrator. ${ }^{23}$ Sengketa akhirnya diputus oleh Permanent Court of Justice (PCA) melalui Hakim Tunggal Max Huber pada 4 April 1928 yang dianggap sebagai putusan terbaik.

Penyelesaian sengketa melalui jalur di luar pengadilan diantaranya terdiri atas :

\section{a. Arbitrasi (Perwasitan)}

Arbitrasi adalah suatu alternatif penyelesaian sengketa melalui pihak ketiga (badan arbitrase) yang ditunjuk dan disepakati para pihak (negara) secara sukarela untuk memutus sengketa yang bukan bersifat perdata dan putusannya bersifat final dan mengikat ${ }^{24}$ Beberapa istilah yang hampir mirip dan bermakna sama diantaranya Tribunal Claim dan Panel. Penyelesaian sengketa melalui arbitrasi sudah dikenal dalam sejarah hukum internasional. ${ }^{25}$ Setelah dua abad lebih jarang digunakan, Amerika Serikat dan Inggris melalui Traktat Jay tahun 1794 memperkenalkan kembali cara arbitrase dengan pembentukan 3 komisi gabungan yang dipimpin oleh seorang wasit (arbitator). ${ }^{26}$ Keberhasilan lembaga ini dalam menyelesaikan Alabama Claims Award (1872) telah membangkitkan kembali berbagai lembaga arbitrasi. Arbitrasi dapat dibentuk dengan mendasarkan pada penyerahan penyelesaian sengketa kepada pihak-pihak tertentu yang disebut

23 Lihat Louis Henkin, International Law: Cases and Materials, St. Paul: West Publ., 3rd.ed., 1991 dan D.J. Harris, Cases and Materials on International Law , London: Sweet and Maxwell, 4th.ed., 1991, hlm. 173 dan 182.

24 Definisi ini dinyatakan oleh Huala Adolf (2004) dan lebih menekankan pada sifat hukum internasional publik.

25 Lembaga arbitrasi sudah dikenal pada zaman Yunani Kuno. Pada saat itu banyak kasus-kasus yang berkaitan dengan masalah lingkungan hidup seperti sengketa-sengketa mengenai sumber-sumber perairan, hak-hak atas sungai sudah ditangani melalui lembaga arbitrasi. Lihat Nussbaum dan Sam Suhaedi, Sedjarah Hukum Internasional, Bina Cipta, Bandung: 1969, HIm 9.

26 Lihat selanjutnya Starke., op.cit., hlm 171-173. 
sebagai arbitrator. Arbitrator ini dipilih secara bebas oleh pihak-pihak yang bersengketa. Penunjukan suatu komisi atau perorangan dari warga negara masingmasing pihak ditambah dengan pihak netral merupakan cara yang umum dipakai. Dapat juga dibentuk arbitrator tunggal yang berasal dari negara netral. Beberapa contoh kasus yang menggunakan arbitrasi dalam sengketa lingkungan hidup maritim adalah Behring Sea Arbitration (1893) (USA v Great Britain), Palma (Miangas) Case (US v. Netherland).

\section{b. Negosiasi}

Jika timbul kasus antar negara, maka wakil-wakil diplomatik atau lembaga pemerintah yang berkepentingan dipertemukan dalam suatu perundingan. Jika negara yang bersengketa menolak untuk melakukan perundingan atau pertemuan dalam satu meja, maka negosiasi dapat mengalami kegagalan atau gagal sama sekali. Resiko kegagalan melalui negosiasi sangat besar karena biasanya hanya melibatkan negara-negara yang bersengketa dan tidak melibatkan pihak ketiga. Dalam Fisheries Jurisdiction Case, Mahkamah Internasional telah menyatakan bahwa negosiasi merupakan metode yang cocok untuk menerapkannya dalam kasus ini. ${ }^{27}$

\section{c. Mediasi}

Jika negosiasi mengalami kegagalan maka dapat dilakukan mediasi. Mediasi umumnya melibatkan pihak ketiga yang bertindak sebagai mediator. Namun hal ini tergantung dari kemauan pihak-pihak yang bersengketa melalui suatu persetujuan tertentu. Mediator biasanya bertindak lebih aktif dengan menawarkan atau mengajukan proposal pada pihak-pihak yang bersengketa. Dalam kasus Indus Water Case (India v Pakistan) tentang sengketa pengalihan arus sungai Indus, International Bank for Reconstructure and Development (IBRD WWorld Bank) pernah memainkan peran sebagai mediator dalam penyelesaian sengketa perairan Indus di tahun $1961 .^{28}$

\section{d. Badan-badan internasional}

Badan-badan internasional seperti badan-badan PBB dan Masyarakat Eropa, aktif terlibat dalam penyelesaian sengketa yang menyangkut masalah lingkungan hidup maritim. Bahkan kadang-kadang badan ini menjembatani sengketa yang

27 Sands, P, op.cit., hlm 164.

28 Merrills, op.cit., hlm 29. 
timbul diantara negara-negara. Seperti kasus perairan Indus dimana peran IBRD/ World Bank cukup efektif dalam menjembatani masalah yang timbul antara Pakistan dan India. Dalam Chorfu Channel Case, Dewan Keamanan awalnya menempuh proses diplomatik diantaranya memanggil Albania yang kemudian membentuk komite untuk penyelidikan bukti-bukti mengenai timbulnya sengketa tersebut melalui Resolusi Dewan Keamanan PBB Nomor 19 (1947) tertanggal 27 Februari 1947. ${ }^{29}$ Setelah melalui jalur diplomatik yang gagal dicapai kesepakatan, maka akhirnya melalui Resolusi Dewan Keamanan PBB Nomor S 324 tertanggal 9 April 1947 meminta kepada Albania dan Inggris untuk segera menyelesaikan kasusnya melalui Mahkamah Internasional (ICJ). ${ }^{30}$

Apabila penyelesaian sengketa gagal dilakukan melalui jalur diplomatik diatas, maka sengketa dapat dibawa ke pengadilan internasional.

\section{Penyelesaian Sengketa Melalui Jalur Peradilan}

Selama ini ada beberapa keputusan para hakim yang dijadikan pedoman dalam penyelesaian sengketa lingkungan hidup maritim diantaranya the Corfu Chanel Case, 1948 (United Kingdom v. Albania), Anglo Norwegian Fisheries Case (UK v. Norway), 1951, Case 3 : Southern Bluefin Tuna Case (New Zealand v. Japan) Case 4 : Southern Bluefin Tuna Case (Australia v. Japan), Gulf of Maine Case (USA v. Canada) 1984, Whaling in the Antarctic (Australia v. Japan: New Zealand intervening), 2010 dan beberapa kasus lainnya. Walaupun bukan merupakan kasus lingkungan hidup an sich, akan tetapi dapat diterapkan dalam penyelesaian persoalan lingkungan hidup maritim khususnya kasus yang menyangkut lintas batas negara atau pengelolaan sumberdaya alam di lingkungan laut.

Dalam mekanisme peradilan internasional yang berkembang saat ini ada beberapa sengketa yang melalui Mahkamah Internasional (ICJ), peradilan yang dibentuk berdasarkan perjanjian internasional tertentu seperti ITLOS, badan peradilan ad hoc seperti arbitrase ataupun bentuk peradilan lainnya. Karena itu

29 "The Corfu Channel Incidents", https://undocs.org/S/RES/19(1947), diunduh pada 28 Juli 2017

$30 \quad$ Ibid. 
masing-masing putusan peradilan memiliki konsekuensi hukum yang berbeda terutama dalam hal keterikatannya. Namun demikian keputusan para hakim ini tetap akan menjadi bahan pertimbangan bagi pengembangan hukum internasional dan dalam hubungan internasional. Hal ini sesuai dengan Pasal 31 Statuta Mahkamah Internasional yang menegaskan :

"d) Sesuai dengan ketentuan-ketentuan dalam pasal 59, keputusan para hakim dan ajaran-ajaran dari para ahli hukum yang tercakup di berbagai negara, sebagai bahan pelengkap untuk penentuan peraturan-peraturan hukum."

Beberapa contoh putusan hakim baik dalam perkara yang diadili melalui badan peradilan internasional maupun pengadilan nasional :

\section{A. Putusan Badan Peradilan Internasional (Sand: 2015)}

\section{A.1. Keputusan Mahkamah Internasional (International Court of Justice)}

Sebenarnya sudah sejak dahulu kala sebelum menjadi Mahkamah Internasional (International Court of Justice atau ICJ), kasus lingkungan hidup khususnya sumberdaya alam dalam arti luas pernah ditangani oleh Mahkamah Internasional Permanen (Permanent International Court of Justice/ PICJ). Contohnya dalam penyelesaian kasus pengelolaan sumberdaya air di antara negara-negara yang berkepentingan telah diterima dua kasus yaitu Diversion of the Waters from the River Meuse Case (Netherland v. Belgium) 1937 dan Territorial Jurisdiction of the International Commission of the River Oder Case (United Kingdom v. Poland) 1929.

Mahkamah Internasional (ICJ) juga telah beberapa kali menangani sengketa yang secara tidak langsung bersinggungan juga dengan persoalan maritim diantaranya putusan Corfu Chanel Case, 1948 (United Kingdom v. Albania), Anglo Norwegian Fisheries Case (UK v. Norway), 1951, Maritime Delimitation in the Caribbean Sea and the Pacific Ocean (Costa Rica v. Nicaragua), 2014, Alleged Violations of Sovereign Rights and Maritime Spaces in the Caribbean Sea (Nicaragua v. Colombia), 2013, Maritime Delimitation in the Indian Ocean (Somalia v. Kenya), 2015, Case concerning Sovereignty over Pedra Branca/Pulau Batu Puteh, Middle Rocks and South Ledge (Malaysia/Singapore), 2008, Whaling in the Antarctic (Australia v. Japan: New Zealand intervening), 2010, Question of the Delimitation of the 
Continental Shelf between Nicaragua and Colombia beyond 200 nautical miles from the Nicaraguan Coast (Nicaragua v. Colombia), 2013 Maritime Delimitation in the Black Sea (Romania v. Ukraine), 2004, Sovereignty over Pulau Ligitan and Pulau Sipadan (Indonesia/Malaysia), 1998 Kasikili/Sedudu Island (Botswana/Namibia) 1997, Fisheries Jurisdiction (Spain v. Canada) 1995 Oil Platforms (Islamic Republic of Iran v. United States of America), 1992 Continental Shelf (Libyan Arab Jamahiriya/Malta), 1982, Delimitation of the Maritime Boundary in the Gulf of Maine Area (Canada/United States of America), 1981 Continental Shelf (Tunisia/Libyan Arab Jamahiriya), 1978, Aegean Sea Continental Shelf (Greece v. Turkey), 1976, Fisheries Jurisdiction (Federal Republic of Germany v. Iceland) 1972 Fisheries Jurisdiction (United Kingdom of Great Britain and Northern Ireland v. Iceland), 1972, North Sea Continental Shelf (Federal Republic of Germany/Netherlands) 1967, North Sea Continental Shelf (Federal Republic of Germany/Denmark), 1967 Antarctica (United Kingdom v. Chile), 1955, Antarctica (United Kingdom v. Argentina), 1955

Beberapa diantaranya bersinggungan dengan lingkungan hidup maritim, namun umumnya kasus-kasus tersebut sangat erat persoalannya dengan masalah perbatasan negara yang kaya akan sumber daya alam hayati maupun non hayati. Dalam kasus perebutan wilayah perairan yang kaya akan sumberdaya perikanan telah diselesaikan dua kasus yang terkenal yaitu Anglo-Norwegian Fisheries Case (United Kingdom v. Norway)(1951) dan Fisheries Jurisdiction (UK v. Iceland v. Federal Republic Germany) (1974). Untuk Gulf of Maine Case (USA v. Canada) 1984, Mahkamah Internasional juga memperhatikan adanya sumberdaya alam yang ada melekat dalam batas-batas geografis. Kasus ini mengenai masalah perbatasan antara Amerika Serikat dan Kanada. Penyelesaian kasus ini diajukan melalui cara ke pengadilan internasional yaitu Mahkamah Internasional. Dalam sengketa ini untuk pertama kalinya Mahkamah Internasional membentuk Kamar Penyelesaian Sengketa (Chamber of Disputte Settlement) berdasarkan pasal 26 ayat (1) Statuta Mahkamah Internasional (ICJ Statute). Persoalan pokok yang diajukan adalah mengenai penetapan perbatasan tunggal (single maritime boundary) yang digunakan. Batas Kanada yang diajukan adalah equidistance line tapi Amerika Serikat menginginkan bahwa perbatasan tergantung dari keadaan yang relevan di wilayah tersebut. Selain itu menurut Kanada, Teluk Maine beserta wilayah yang berdekatan termasuk 
bagian penting karena memunyai hubungan yang kompleks dan memiliki proses biologis yang penting. Juga wilayah ini merupakan eksosistem laut yang penting di wilayah utara. Di lain pihak, Amerika Serikat menyatakan bahwa wilayah ini memiliki karakteristik berdasarkan 3 prinsip rezim ekologi. Dalam hal ini ternyata Teluk Maine juga membentuk komunitas flora dan funa dalam semua siklus jaring makanan dari yang terkecil hingga ikan yang terbesar.

Dalam kasus-kasus perbatasan yang menyangkut landas kontinen yang kaya akan sumberdaya alam non hayati Mahkamah Internasional juga telah menerima dan menyelesaikan beberapa kasus seperti North Sea Continental Shelf (1969), Continental Shelf (Libyian Arab Jamahiriya v. Malta) (1985) dan Continental Shelf ( Tunisia v. Libya) (1982). Mahkamah Internasional sebagai badan peradilan utama di dunia, memiliki kebebasan untuk mendorong berkembangnya hukum internasional secara progresif sesuai Pasal 13 Piagam PBB (Charter of the United Nations).

\section{A.2. Putusan Mahkamah Internasional Hukum Laut (International Tribunal Law of the Sea/ITLOS)}

Mahkamah Hukum Laut Internasional (ITLOS) didirikan berdasarkan United Nations Convention on the Law of the Sea (UNCLOS) tahun 1982. Terdiri dari 21 Hakim dan menangani berbagai kasus terkait hukum laut yang dimulai sejak tahun 1997. Kasus pertama yang diputuskan adalah Case No. 1 dan 2 : the $M / V$ "Saiga" Case yang diajukan oleh Saint Vincent dan Grenadines v. Guena sejak 13 November 1997 hingga diputuskan pada 4 Desember 1997. Beberapa kasus yang diputuskan terkait dengan lingkungan hidup maritim diantaranya Case No. 10 : The MOX Plant Case (Ireland v. United Kingdom) tahun 2001, Case No. 12 : Concerning Land Reclamation by Singapore in and Around the Straits of Johor, (Malaysia v Singapore) tahun 2003, Case No.7 : Concerning the Conservation and Sustainable Exploitation of Swordfish Stocks in the South-Eastern Pacific Ocean (Chile v. European Union) tahun 2009, Case No. 17 : Responsibilities and Obligations of States Sponsoring Persons and Entities with Respect to Activities in the Area, (Advisory Opinion/AO) oleh International Sea Bad Authority (ISA) tahun 2011, Case No. 21 : Request for an Advisory Opinion submitted by the SubRegional Fisheries Commission (SRFC) (Advisory Opinion/AO) oleh Sub-Regional 
Fisheries Commission (SRFC) tahun 2015. Case No. 22 : The "Artic Sunrise" Case (Kingdom of the Netherlands v. Russian Federation) tahun 2013.

Putusan ITLOS dalam Advisory Opinion on Responsibilities and Obligations on States in the Area tahun 2011 juga telah memperkuat prinsip-prinsip hukum internasional yang sedang berkembang seperti prinsip Analisis Mengenai Dampak Lingkungan (AMDAL) yang merupakan Prinsip 17 Deklarasi Rio tahun 1992. Sedangkan prinsip pertukaran informasi juga disinggung dalam The MOX Plant Case (Ireland v. United Kingdom) tahun 2001. Pada sengketa The Artic Sunrise (Kingdom of the Netherlands v. Russia Federation) tahun 2013, Greenpeace sebagai NGO Internasional telah bertindak untuk pertama kalinya di peradilan internasional sebagai teman pengadilan (amicus curiae) pada peradilan Mahkamah Arbitrase (PCA) dan Mahkamah Hukum Laut (ITLOS) walaupun akhirnya ditolak ${ }^{31}$

\section{A.3. Putusan Mahkamah Pidana Internasional (International Criminal Court/ICC)}

Statuta Roma (1998) sebagai dasar pendirian Mahkamah Pidana Internasional (ICC) menegaskan bahwa kejahatan perang (war crime) juga berhubungan dengan lingkungan hidup yang hal ini tercantum dalam Pasal 8 (2) bagian (b) (iv),(v),(ix),(xvi),(xvii) dan (xviii). Dua kasus yang sedikit menyinggung persoalan lingkungan hidup seperti : Situation in Darfur, Sudan Case (ICC-02/05) dimana Presiden Sudan, Omar Al Bashir melakukan tindakan genocide, kejahatan perang dan kejahatan terhadap kemanusiaan termasuk kejahatan terhadap masyarakt yang memiliki sumur dan air yang kemudian diracuni oleh tentara Presiden Sudan. Dalam kasus lainnya yaitu Kasus Kejahatan Perang yang dilakukan oleh Presiden Irak, Sadam Hussein (Irak War Crime Case), dimana dalam Pre-elimenary Examination (2013) dinyatakan bahwa :

"65. Impact of crimes may be as sessed in light of, inter alia, the sufferings endured by the victims and their increased vulnerability; the terror subsequently instilled, or the social, economic and environmental damage inflicted on the affected communities

31 "International Tribunal Law of the Sea Year 2013 : List of cases No : 22" dalam https://www. itlos.org/fileadmin/itlos/documents/cases/case no.22/Order/C22 Ord 22112013 orig_Eng.pdf dan PCA Case No. 2014-02 dalam http://www.pcacases.com/web/sendAttach/1325, diunduh pada 28 Juli 2017 
Dalam Prosecutor v. Jean-Pierre Bemba (2016) menegaskan bahwa para pejabat yang menentukan komando/perintah serta bawahannya dibawah Pasal 28 ICC merupakan peran kunci dari pertanggungjawaban dan ini merupakan prinsip atas perintah dapat dipertanggungjawabkan the principle of responsible command yang mana mengakhiri kekebalannya dan dapat bertindak untuk membantu mencegah kejahatan ${ }^{32}$

\section{A.4. Putusan Mahkamah Arbitrase Internasional (Permanent Court of Arbitration/PCA) ${ }^{33}$}

Sebagai salah satu badan peradilan internasional yang akhir-akhir ini populer, Mahkamah Arbitrase Permanen (The Permanent Court of Arbitration/ PCA) berdiri tahun 1899 dan berkedudukan di Den Haag, Negeri Belanda. Dalam aktifitasnya yang berkembang terus, PCA telah menerima berbagai jasa penyelesaian sengketa internasional di luar makna arbitrase seperti konsiliasi, fact-finding commission atau inquiry (komisi penyelidik), jasa baik dan mediasi. ${ }^{34}$ Perkembangan secara keorganisasian dan prosedural dalam proses peradilan dimana Mahkamah Arbitrase Permanen (The Permanent Court of Arbitration/ PCA) pada tahun 2002 telah berhasil mengadopsi aturan tambahan (optional rules/OR) yang disebut Optional Rules for Arbitration of Disputes Relating to Natural Resources and/or the Environment dan tahun 2011 Optional Rules for Arbitration of Disputes Relating to Outer Space Activities dimana lingkungan hidup menjadi bagian penting dalam OR ini. PCA pernah menangani kasus yang kemudian dihubungkan dengan persoalan lingkungan hidup seperti dalam Iron Rhine (Ijzeren Rijn) Railway Case (Belgium v. Netherland) yang diputuskan tahun 2005.

Pada 23 April 2013, Timor-Leste mengajukan sengketa melawan Pemerintah Australia berdasarkan Traktat Laut Timur (Timor Sea Treaty) 20 Mei 2002 berdasarkan Paragraph (b) of Annex B Pasal 23. Sengketa ini mengenai intepretasi perjanjian internasional terutama terkait dengan pemanfaatan sumberdaya alam di laut Timor. Kasus ini kemudian diregistrasi dengan nomor

32 Sebagian tulisan ini diambil dari Andreas Pramudianto, Hukum Lingkungan Internasional, CV Rajawali: Jakarta, 2017, hlm. 181-182

33 Ibid, hlm. 183-184.

34 Optional Rules for Arbitrating Disputes between Two States tertanggal 20 Oktober 1992. 
PCA Case No. 2013-14 : Arbitration under the Timor Sea Treaty (Timor Leste v. Australia). Berdasarkan Annex VII UNCLOS 1982, 4 Oktober 2013, Pemerintah Kerajaan Belanda mengajukan sengketa melawan Pemerintah Federasi Russia mengenai sengketa kapal Greenpeace "Artic Sunrise". Sengketa berkenaan dengan penumpang, perampasan dan penahanan awak kapal maupun kapal milik Greenpeace oleh pemerintah Russia pada waktu ditangkap di Zona Ekonomi Ekslusif. Sengketa kemudian diajukan ke Mahkamah Arbitrase Permanen (PCA) dengan registrasi PCA Case No. 2014-02 : The Artic Sunrise Arbitration (Netherlands v. Russia).

Dalam sengketa Laut Cina Selatan atau In the Matter of South China Sea Arbitration, PCA Case No. 2013-19 12 Juli 2016, Mahkamah Arbitrase Permanen telah memutuskan perkara ini yang walaupun perkara ini menyangkut masalah kemananan, namun salah satu putusannya juga menyinggung masalah lingkungan hidup maritim khususnya terumbu karang yang rusak akibat pembangunan pelabuhan di pulau dan karang Laut Cina Selatan. Seperti dinyatakan dalam putusannya :

1178.....China has aggravated the Parties' dispute with respect to the protection and preservation of the marine environment by causing irreparable harm to the coral reef habitat at Cuarteron Reef, Fiery Cross Reef, Gaven Reef (North), Johnson Reef, Hughes Reef, Subi Reef, and Mischief Reef. The Tribunal has already found that China has seriously violated its obligation to preserve and protect the marine environment in the South China Sea.......In practical terms, neither this decision nor any action that either Party may take in response can undo the permanent damage that has been done to the coral reef habitats of the South China Sea......

\section{A.5. Peradilan Arbitrase Lainnya}

Badan Arbitrase di luar PCA memang sudah ada yang berkembang hingga saat ini diantaranya diantaranya Sweden`s Arbitration Institute yang didirikan tahun 1917, International Chamber of Commerce (ICC) yang didirikan di Paris, Perancis tahun 1923. Walaupun The Trial Smelter Case (1941) yang merupakan kasus yang ditangani melalui peran arbitrasi yang dibentuk Amerika Serikat dan Kanada bukan merupakan kasus lingkungan hidup 
maritim, namun keputusan badan arbitrase ini ternyata telah mempengaruhi terbentuknya Prinsip 21 Deklarasi Stockholm tahun 1972 yang juga dijadikan dasar dalam beberapa pasal di UNCLOS 1982 seperti Bab XII, Bagian 1 Pasal 193. Sedangkan dalam Behring Sea Fur Arbitration (USAv Great Britania) tahun 1893 dimana keputusan arbitrasi ini telah mempengaruhi pembentukan Treaty for the Preservation and Protection of Fur Seals tahun 1911. Peradilan arbitrase lainnya dibentuk juga oleh World Bank melalui International Center for Settlement for Investment Disputes (ICSID) yang menangani kasus Methanex Corporation v. United States of America pada tahun 2001 yang membuat terobosan dengan membuka intervensi dan partisipasi diluar pihak bersengketa sebagai Amici Curiae. ${ }^{35}$ Dalam kasus lainnya Azinian, Davitian and Baca v. Mexico (1998) dan Waste Management v. Mexico (2004) merupakan kasus yang berhubungan dengan limbah bahan berbahaya dan beracun yang diputuskan oleh ICSID. Dalam kasus kapal laut Rainbow Warrior milik Greenpeace yang dibom oleh Agen Rahasia Perancis, disepakati juga diselesaikan melalui arbitrase Sekretariat Jenderal PBB yang ditandatangani di Paris, Perancis pada 9 Juli 1986. ${ }^{36}$

\section{A.6. Putusan Badan Peradilan Regional}

Badan peradilan regional telah terbentuk di berbagai benua atau region tertentu. Terbentuknya didasarkan pada organisasi regional ataupun kebutuhan negara-negara di regional tersebut. Organisasi yang cukup kuat secara regional seperti Uni Eropa dengan keberadaan Mahkamah Eropa (European Court of Justce/ECJ) telah menjadi contoh di banyak benua, Model Mahkamah Eropa ini telah menjadi model terbentuknya East African Court of Justice pada Masyarakat Afrika Timur (East African Community) dan Andean Tribunal of Justice, pada Andean Community. ${ }^{37}$ NAFTA/UNCITRAL juga membentuk badan peradilan melalui arbitrase dalam Ethyl Corporation $v$.

35 Rebasti, E dan Luisa Vieruci. “A Legal Status for NGO in Contemporary International Law?" Paper in Workshop Legal for NGO in Contemporary International Law : A Contributuon to the Debate on "Non State Actors" and Public International Law at the Beginning of the Twenty-First Century, European University Institute (EUI) of Florence on 15-16 November 2002.

36 http://legal.un.org/riaa/cases/vol XX/215-284.pdf. Lihat juga Andreas Pramudiantio loc. cit.

37 Borzel, Tanja A dan Thomas Risse. The Oxford Handbook Comparative Regionalism, Oxford University Press, 2016, hlm. 545. Lihat juga Andreas Pramudianto, loc.cit. 
Canada (1999) yang mendorong agar para pihak taat pada aturan lingkungan hidup (compliance regulation) domestik. Dalam S.D Mayers.Inc v. Canada sengketa antara Amerika Serikat dengan Kanada mengenai pembuangan limbah PCB berdasarkan Basel Convention 1989 juga telah diputuskan. ${ }^{38}$

\section{A.7. Putusan Badan Peradilan Khusus ${ }^{39}$}

Beberapa badan peradilan khusus telah berhasil dibentuk seperti Mahkamah Hak Asasi Manusia Eropa (European Court of Human Right/ECHR), Mahkamah Hak Asasi Antar Amerika (The Inter American Court of Human Right) IACHR). Di Afrika keberadaan peradilan khusus Hak Asasi Manusia yaitu Mahkamah Afrika mengenai Hak Asasi Manusia dan Rakyat (African Court on Human and Peoples Right/ACHPR) dan bersama peradilan tidak tetap yaitu Mahkamah Afrika (African Court of Justice /ACJ) akan digabungkan menjadi Mahkamah Keadilan Afrika dan Hak Asasi Manusia (African Court of Justice and Human Right/ACJHR) berdasarkan keputusan KTT Uni Afrika (Africa Union) di tahun 2008. IACHR dalam salah satu kasusnya telah memperjelas hubungan antara lingkungan hidup dengan hak asasi manusia seperti dalam kasus The Yanomami Indians case, resolution no 12/85 case no 7615 Brazil, 5 Maret 1985. Sementara itu dalam kasus Lopez v.Ostar Case tahun 1994 (application no. 16798/90) ECHR telah menegaskan bahwa terdapat pengertian perluasan pasal 8 yang berlaku dalam hukum lingkungan internasional regional yaitu European Convention for the Protection of Human Rights and Fundamental Freedom tahun 1953 yang tidak hanya persoalan hak asasi manusia semata akan tetapi juga menyangkut sumber pencemar (pollution resources) yang dapat melanggar hak asasi individu dan keluarga khususnya hak untuk mendapatkan kesehatan.

\section{A.8. Putusan Badan Peradilan Lainnya(WTO $)^{40}$}

Beberapa Peradilan Internasional lainnya dibentuk dalam kerangka organisasi internasional atau perjanjian internasional yang juga bersifat khusus. Bentuk badan peradilan atau badan penyelesaian sengketa tersebut sesungguhnya lebih tepat disebut quasi-pengadilan dikarenakan bukan pengadilan sesungguhnya. Jika pihak-pihak bersengketa, maka akan diadili

38 Andreas Pramudianto, op.cit., hlm. 185

39 Ibid., hlm. 185-186.

$40 \quad$ Ibid., hlm. 186-187. 
oleh badan tersebut dan putusannya dapat bersifat mengikat. Sebelum WTO terbentuk yaitu GATT pernah menyelesaikan sengketa yang timbul antara Amerika Serikat dan Mexico mengenai metode penangkapan ikan tuna. Sengketa ini menerapkan cara penyelesaian melalui peraturan badan internasional yaitu General Agreement Tariff and Trade (GATT). Peristiwa ini bermula dari tindakan pemerintah Amerika Serikat yang melarang impor ikan tuna yang berasal dari Mexico. Hal ini merugikan Mexico yang kemudian gugatan diajukan melalui GATT Disputte Pannel I. Dalam sidang tersebut Amerika Serikat menyatakan bahwa negaranya memiliki alasan kuat yaitu pelarangan atas penangkapan ikan tuna yang dilakukan melalui jaring nelayan Mexico ternyata juga telah membunuh anak ikan lumba-lumba (dolphin) yang dilindungi berdasarkan Mamalia Protection Act 1972. Namun tindakan ini menurut Mexico merupakan upaya terselubung Amerika Serikat dengan menggunakan masalah lingkungan hidup menjadi alat perdagangan. Dari hasil kasus ini nampak bahwa kaitan antara perdagangan dan lingkungan hidup semakin erat. Sementara ini GATT menunda keputusannya.

Kasus dalam World Trade Organization (WTO) sekarang ini seperti dalam WTO Appellate Body yang pernah menangani sengketa perdagangan terkait lingkungan hidup maritim seperti dalam putusannya United States - Import Prohibition of Certain Shrim and Shrimp Product (1998) antara USA dengan negara-negara Asia.

\section{B. Putusan Badan Pengadilan Nasional ${ }^{41}$}

Beberapa negara telah membentuk badan peradilan khusus untuk menangani perkara lingkungan hidup seperti National Environmental Tribunal di Pakistan, National Environmental Appellete Authority (NEAA) di India, Environmental National Dispute Resolution Commission di Korea, Environmental National Dispute Coordination Commission di Jepang. ${ }^{42}$ Putusan pengadilan nasional dapat menjadi bahan pertimbangan untuk dapat dibentuknya perangkat hukum internasional khususnya perjanjian internasional, sehingga putusan badan peradilan nasional

41 Ibid

42 "Asian Judges : Green Court and Tribunal, and Environmental Justice" dalam Law and Policy Reform Brief No. 1 April 2010 dalam https://www.adb.org/sites/default/files/ publication/27654/2010-brief-01-asian-judges.pdf, diunduh pada 28 Juli 2017 
juga merupakan sumber hukum khususnya hukum lingkungan internasional. Dalam kasus-kasus pencemaran minyak di laut, banyak permasalahan tanggungjawab lingkungan (environmental liability) serta ganti rugi (compensation) seperti diamanatkan dalam Deklarasi Stockholm 1972, untuk dikembangkan dalam hukum nasional. Kasus-kasus pencemaran minyak yang masuk peradilan nasional seperti kasus karamnya kapal tanker Argo Merchant tahun 1976 yang kemduain disidangkan dalam US District Court tahun 1980 dan beberapa kasus sesudahnya seperti Olympic Games (1976), Sanswena (1976) dan Daphne (1976) yang kemudian mendorong diperbaharuinya ketentuan dalam Marine Pollution Convention (MARPOL) 1973/1978.

Dalam Kasus Patmos mengenai pencemaran minyak yang menyebabkan kerusakan lingkungan di pantai Italia. Kasus ini diselesaikan dengan cara mengajukan perkara pada pengadilan nasional. Peristiwa ini bermula pada 21 Maret 1985 dimana suatu kapal tanker berbendera Yunani "Patmos" bertubrukan dengan kapal tanker berbendera Spanyol "Castillo de Monte Aragon". Akibat tubrukan ini sekitar 1300 ton dari total 80.000 ton minyak yang dibawa "Patmos" tumpah di laut yang kemudian tumpahan ini mencapai pantai Sisilia. Gugatan diajukan oleh pemerintah Italia ke pengadilan Messina dengan alasan adanya kerusakan ekologis dengan berdasar pada Civil Liability Convention dan Fund Convention. Pada tanggal 30 Juli 1986 pengadilan menolak gugatan pemerintah Italia yang diwakili Kementerian Perdagangan Laut dengan alasan kerusakan ekologis tidak terbukti terjadi pada pantai Italia. Gugatan banding diajukan pada 30 Maret 1989 dan pengadilan banding Messina mengakui kalim yang diajukan pemerintah Italia.

Contoh yang terkenal adalah hasil putusan pengadilan Amerika Serikat melalui putusan Mahkamah Agung Amerika Serikat (US Supreme Court) dalam kasus New Jersey v. City of New York tahun 1931 (283 US.473) mengenai pencemaran pantai dan laut teritorial akibat pembuangan limbah kota. Hasil putusan ini menjadi sumber hukum penting dalam pembentukan Geneva Convention of the High Seas 1958 khususnya mengenai pencemaran pantai. (Kiss:1976). Beberapa kasus lainnya seperti Japan Whalling Association v. American Cetacean Society (1986), Defender of Wildlife, Inc v. Endangered Species Scientific Authority (1981), Environmental Defense Fund v. Massey (2010) merupakan contoh kasus lingkungan hidup maritim. 
Dengan demikian putusan pengadilan internasional seperti penerapan perjanjian internasional dalam hukum nasional dapat menjadi pembelajaran penting seperti dinyatakan oleh Wirth (1999) dalam Pramudianto (2017) yang menegaskan :

"The little-taught Japan Whaling case, concerning domestic implementation of the Whaling Convention, is an excellent example of the way in which legal and policy considerations unique to foreign relations may generate conflicts with domestic statutory mandates".

\section{Penutup}

Kesimpulan dari artikel ini telah menunjukan bahwa diplomasi dan putusan peradilan internasional mampu memberikan dasar hukum dan petunjuk hukum bagi negara-negara dan aktor bukan negara dalam hubungan internasional. Salah satu putusan peradilan internasional khususnya Permanent Court Arbitration (PCA) Case No. 2013-19 in the matter of the South China Sea Arbitration (The Republic of Philipines v. The People Republic of China) telah memperkuat status hukum internasional suatu ekosistem khususnya perlindungan terhadap ekosistem terumbu karang di wilayah Laut China Selatan. Selain itu penegakan prinsip-prinsip perlindungan lingkungan hidup maritim juga menjadi penting. Di sisi lain, pentingnya pengembangan kelembagaan dalam hukum internasional juga perlu diperhatikan. Pembentukan kelembagaan untuk penyelesaian sengketa seperti komisi bersama (joint commission) atau semacam komisi penyelidik (Security Council sub committee) menjadi penting dalam penyelesaian kasus the Trial Smelter Case (1941) dan the Corfu Chanel Case (1948). Dalam International Tribunal Law of the Sea (ITLOS) Case No. 22 : The "Artic Sunrise" Case (Kingdom of the Netherlands v. Russian Federation) tahun 2013 berperannya Greenpeace sebagai salah satu NGO internasional yang merupakan entitas bukan subjek hukum internasional bertindak sebagai amicus curiae di peradilan internasional (ITLOS dan PCA) menjadi sangat penting dalam kerangka pengembangan hukum internasional khususnya hukum lingkungan internasional. Walaupun dalam dua peradilan ini, Greenpeace telah ditolak, namun akan menjadi pembelajaran di kemudian hari. Berbagai kasus lingkungan 
hidup maritim tersebut yang muncul sesungguhnya tidak terlepas dalam berbagai kepentingan khususnya kepentingan nasional yang dapat berbenturan dengan kepentingan nasional lainnya atau bahkan kepentingan global internasional. Sebagaimana diungkapkan oleh Kementerian Luar Negeri Cina dalam kasus Laut China Selatan yang mengatakan bahwa negara Tiongkok adalah yang pertama kali menemukan dan mengeksploitasi pulau-pulau di Laut Cina Selatan, "sehingga memiliki kedaulatan teritorial serta hak dan kepentingan". Pernyataan ini tentu menjadi alasan sengketa bagi negara lain yang memiliki kepentingan yang sama, sehingga dapat menimbulkan ketegangan dan dapat menimbulkan tindakan kekerasan yang sesungguhnya tidak menyelesaikan sengketa, bahkan menimbulkan masalah baru. Karena itu penyelesaian sengketa maritim melalui diplomasi dan peradilan internasional menjadi sangat penting dalam kerangka peredaan ketegangan (détente) hubungan bilateral, regional maupun multilateral. 


\section{DAFTAR PUSTAKA}

\section{$\underline{\text { I. Buku }}$}

Akehurst, Michael. 1983. A Modern Introduction to International Law, 4th Edition,George Allen \& Unwin (Publishers) Ltd.

Anton, Donald K et al. 2005. International Law : Cases and Materials, Oxford University Press,

Ball, Simon \& Stuart Bell. 1992. Environmental Law, Blackstone Press Limited, London.

Borzel, Tanja A dan Thomas Risse.2016. The Oxford Handbook Comparative Regionalism, Oxford University Press.

D.J. Harris, Cases and Materials on International Law , London: Sweet and Maxwell, 4th.ed., 1991

Henkin, Louis. 1991. International Law: Cases and Materials, St. Paul: West Publ., 3rd.ed., 1991

Merrills, J.G. 1986. Penyelesaian Sengketa Internasional diterjemahkan oleh Achmad Faudzan, Tarsito, Bandung.

Nussbaum, Arthur dan Sam Suhaedi. 1969. Sedjarah Hukum Internasional, Bina Cipta, Bandung.

Pramudianto, Andreas. 2017. Hukum Lingkungan Internasional, Penerbit CV Rajawali, Jakarta.

.2008. Diplomasi Lingkungan, Penerbit UI Press, Jakarta.

Rasjid, Abdul. 1985. Upaya Penyelesaian Sengketa Antar Negara melalui Mahkamah Internasional, PT Bina Ilmu, Surabaya.

Sands, Phillipe. 1993. Greening International Law, Earthscan Publication, London.

Starke, J.G. 1989. Pengantar Hukum Internasional diterjemahkan oleh Sumitro LS Danuredjo, Aksara Persada Indonesia, Jakarta.

\section{$\underline{\text { II. Makalah }}$}

Adolf, Huala. 2004. Hukum Penyelesaian Sengketa, Tanpa Penerbit. Diakses melalui http://blog.ub.ac.id/devitrirahayu/files/2012/03/3-HUKUMPENYELESAIAN-SENGKETA-INTERNASIONAL1.pdf 
Rebasti, E dan Luisa Vieruci. 2002. A Legal Status for NGO in Contemporary International Law ? Paper in Workshop Legal for NGO in Contemporary International Law : A Contributuon to the Debate on "Non State Actors" and Public International Law at the Beginning of the Twenty-First Century, European University Institute (EUI) of Florence on 15-16 November 2002.

Cooper, Catherine A. 1986. The Management of International Environmental Dispute in the Context of Canada-United States Relations : A Survey and Evaluation of Techniques and Mechanisms dalam Canadian Year Book of International Law, University of British Columbia Press.

Desai, Bharat. 1993. The Bhopal Gas Leak Disaster Litigation: An Overview dalam Asian Year Book of International Law, Martinus Nijhoff, Amsterdam.

Jonsson, Crister dan Karin Aggestam. 2007. Diplomacy and Conflict Resolution, Prepared for the NISA conference on "Power, Vision and Order in World Politics", Odense

Keith A Muray.1972. The Trial Smelter Case : International Air Pollution in the Columbia Valley dalam http : www. ojs.library.ubc.ca

Ospina, E Valencia.1993. The International Court of Justice and International Environmental Law dalam Asian Year Book of International Law, Martinus Nijhoff, Amsterdam.

Pramudianto, A. 1995. Soft Law Dalam Perkembangan Hukum Lingkungan Internasional dalam Majalah Hukum Pro Justitia Tahun XIII Nomor 4 Oktober 1995. 1998. Penyelesaian Sengketa Dalam hukum Lingkungan Internasional. Dalam Majalah hukum Pro Justitia Tahun XVI No.2 April 1998.

2006. Penyelesaian Sengketa Lingkungan Hidup Dalam Perjanjian Internasional Bidang Pengelolaan B3 dan Limbah B3 dalam Jurnal Lingkungan dan Pembangunan Volume 26 Nomor 1 Tahun 2006.

\section{Dokumen lainnya}

UNEP. 1991. Register of International Treaties \& Other Agreements in the Field of the Environment, UNEP, Nairobi. . 1986. Statuta Mahkamah Internasional, Penerbit United Nations Information Center (UNIC) 
ICJ Communique 93/20, 19 Juli 1993

The Corfu Channel Incidents dalam https://undocs.org/S/RES/19(1947)

The Corfu Channel Incidents dalam https://undocs.org/S/RES/22(1947

International Tribunal Law of the Sea Year 2013 : List of cases No : 22 dalam https:/ / www.itlos.org/fileadmin/itlos/documents/cases/case_no.22/Order/C22_ Ord_22_11_2013_orig_Eng.pdf

PCA Case No. 2014-02 dalam http:/ / www.pcacases.com/web/sendAttach/1325

Asian Judges : Green Court and Tribunal, and Environmental Justice dalam Law and Policy Reform Brief No. 1 April 2010 dalam https://www.adb.org/ sites/default/files/publication/27654/2010-brief-01-asian-judges.pdf

http://legal.un.org/riaa/cases/vol_XX/215-284.pdf

https ://www.PCA.org/cases/list

http:/ / www.icj-cij.org/docket/index.php?p1=3\&p2=2

https://www.itlos.org/cases/list-of-cases/

http:/ / ekonomi.kompas.com/read/2017/07/16/113255326/beijing-protesindonesia-ubah-laut-china-selatan-jadi-laut-natuna 